\title{
HUBUNGAN ANTARA KOMUNIKASI INTERPERSONAL DENGAN PENGETAHUAN KONSEP EKONOMI SISWA PADA SMA HUTAMA DI PONDOK GEDE
}

\author{
Dr. Siti Nurjannah, SE., M.Si. \\ (Dosen Fakultas Ekonomi UNJ) \\ Winda Marya Loysa, S.Pd. \\ (Alumni Fakultas Ekonomi UNJ)
}

\begin{abstract}
ABSTRAK
Penelitian ini bertujuan untuk mengetahui apakah terdapat hubungan antara komunikasi interpersonal dengan pengetahuan konsep ekonomi siswa dan mengetahui seberapa erat hubungan antara komunikasi interpersonal dengan pengetahuan konsep ekonomi siswa pada SMA Hutama di Pondok Gede. Penelitian ini dilakukan selama tiga bulan terhitung bulan September sampai November 2011. Metode penelitian yang digunakan adalah metode survey dengan pendekatan korelasional. Populasi penelitian ini adalah seluruh siswa SMA Hutama Pondok Gede sebanyak 438 siswa, dan populasi terjangkaunya adalah siswa IPS kelas XI yang berjumlah 106 siswa. Sampel yang digunakan adalah 84 orang siswa dengan menggunakan teknik sampel acak sederhana. Data variabel $Y$ (pengetahuan konsep ekonomi siswa) dan data variabel $X$ (komunikasi interpersonal) merupakan data primer, instrument yang digunakan untuk variabel $\mathrm{Y}$ adalah berbentuk tes objektif dan untuk variabel $\mathrm{X}$ adalah berbentuk kuesioner. Sebelum digunakan, dilakukan uji validitas konstruk (Construct Validity) melalui proses validasi yaitu perhitungan koefisien korelasi skor butir dengan skor total dan uji reliabilitas dengan rumus Alpha Cronbach. Hasil reliabilitas instrument variabel $Y$ (pengetahuan konsep ekonomi siswa) sebesar 0,889 , sedangkan hasil reliabilitas instrument variabel $X$ (komunikasi interpersonal) sebesar 0,910. Uji persyaratan analisis yang dilakukan adalah dengan mencari persamaan regresi yang didapat adalah $\hat{Y}=0,44+0,194 X$. Hasil uji normalitas lilifors menghasilkan Lhitung $=0,077$ sedangkan Ltabel untuk $n=84$ pada taraf signifikansi 0,05 adalah 0,097 . Karena Lhitung $<$ Ltabel variabel $X$ dan $Y$ berdistribusi normal. Pengujian hipotesis dengan uji keberartian regresi menghasilkan Fhitung $(37,40)>$ Ftabel $(3,91)$ yang berarti persamaan regresi tersebut signifikan. Uji kelinieran regresi menghasilkan Fhitung $(1,38)<$ Ftabel $(1,71)$ sehingga disimpulkan bahwa persamaan regresi tersebut linear. Uji koefisiensi korelasi product moment menghasilkan rhitung $=0,560$. Selanjutnya dilakukan uji keberartian koefisien korelasi dengan menggunakan uji-t, menghasilkan thitung $(6,12)>$ ttabel $(1,67)$. Hasil penelitian tersebut menyimpulkan bahwa terdapat hubungan positif antara komunikasi interpersonal dengan pengetahuan konsep ekonomi siswa. Dengan uji koefisien determinasi atau penentu diperoleh hasil $31,32 \%$ variabel pengetahuan konsep ekonomi ( $Y$ ) ditentukan oleh komunikasi interpersonal $(\mathrm{X})$.
\end{abstract}




\section{PENDAHULUAN}

Pendidikan adalah salah satu faktor utama dari suatu negara yang harus didahulukan dan merupakan skala prioritas yang juga wajib diagendakan dan diawasi pemerintah dalam pelaksanaannya. Pendidikan yang berkualitas akan menghasilkan manusia-manusia pilihan yang memiliki kemampuan dalam bidangnya sehingga mampu menentukan berkembang tidaknya suatu negara dan merupakan tanggung jawab dari seluruh warga negara. Setiap warga negara Indonesia berhak untuk memperoleh pendidikan serta kesempatan dalam mengikuti pendidikan dan mendapatkan pengetahuan, kemampuan dan keterampilan. Profesionalisme dalam dunia pendidikan yang bermuara pada peningkatan kualitas pembelajaran di kelas, tidak dapat di abaikan. Selain tuntutan tersebut, masyarakat pun menginginkan kebutuhan akan informasi dan komunikasi yang tepat, cepat dan akurat, dimana informasi dan komunikasi sangat berpengaruh pada kemajuan dibidang pendidikan.

Pendidikan mempunyai arti yang sangat penting dalam kehidupan kita, baik dalam kehidupan individu, bangsa maupun negara. Oleh karena itu pendidikan harus dilaksanakan dengan sebaik-baiknya, sehingga sesuai dengan tujuan. Keberhasilan suatu bangsa terletak pada mutu pendidikan yang dapat meningkatkan pengetahuan dan kualitas sumber daya manusianya. Pendidikan pada dasarnya suatu proses untuk membantu manusia dalam mengembangkan dirinya, sehingga mampu menghadapi segala perubahan dan permasalahan dengan sikap terbuka serta pendekatan-pendekatan yang kreatif tanpa harus kehilangan identitas dirinya. Sekolah merupakan bagian dari sistem pendidikan formal yang mempunyai aturan-aturan jelas atau lebih dikenal dengan GBPP (Garis-garis Besar Program Pengajaran). Ekonomi merupakan salah satu cabang ilmu IPS yang berperan sangat esensial dalam perkembangan sains dan teknologi. Oleh karena itu, siswa dituntut untuk menguasai materi pelajaran ekonomi secara tuntas. Hal ini sejalan dengan tujuan pembelajaran ekonomi yang tercantum dalam kurikulum, yaitu agar siswa memahami atau menguasai penerapan pengetahuan konsep ekonomi dan saling keterkaitannya serta mampu menerapkan berbagai konsep ekonomi untuk memecahkan masalah dalam kehidupan sehari-hari dan teknologi secara ilmiah.

Pada SMA Hutama Pondok 
Gede rata-rata ujian nasional untuk mata pelajaran

B. Indonesia mencapai 7,55, B. Inggris 7,88, Matematika 7,7 dan Ekonomi 7,37, Sosial 8, 34 dan Geografi 7, 81. ${ }^{1}$ Berdasarkan data hasil ujian nasional secara keseluruhan, ekonomi merupakan mata pelajaran dengan nilai terendah. Hal ini berarti bahwa mata pelajaran ekonomi merupakan mata pelajaran yang lebih sulit dibandingkan dengan kedua mata pelajaran lain yang turut diujikan dalam ujian nasional. Untuk mencapai nilai pelajaran ekonomi menjadi lebih baik, maka pengajaran ekonomi harus dilaksanakan dengan sebaik-baiknya sehingga memperoleh hasil yang diharapkan. Keberhasilan pengajaran ekonomi ini ditentukan oleh besarnya partisipasi siswa dalam mengikuti pembelajaran, makin aktif siswa mengambil bagian dalam kegiatan pembelajaran, maka makin berhasil kegiatan pembelajaran tersebut. Tanpa aktivitas belajar tidak akan memberikan hasil yang baik. Karena tujuan utama dari proses belajar adalah tercapainya perubahan dari yang tidak tahu menjadi tahu, sehingga dari hasil belajar tersebut akan tercipta manusiamanusia yang bertanggung jawab dan berdisiplin adalah memiliki sikap-sikap yang sesuai dengan penjabaran tujuan pengajaran yang tersebut dalam
GBPP. Banyak faktor yang mempengaruhi seorang siswa dalam meningkatkan pengetahuan konsep ekonomi, diantaranya pengalaman, lingkungan, tingkat pendidikan, IQ dan komunikasi. Dalam meningkatkan pengetahuan konsep ekonomi dipengaruhi oleh pengalaman. Pengalaman sebagai sumber pengetahuan adalah suatu cara untuk memperoleh kebenaran pengetahuan dengan cara mengulang kembali pengetahuan yang diperoleh dalam memecahkan masalah yang dihadapi masa lalu. Pengalaman belajar dalam bekerja yang dikembangkan memberikan pengetahuan dan keterampilan profesional serta pengalaman belajar selama bekerja akan dapat mengembangkan kemampuan mengambil keputusan yang merupakan manifestasi dari keterpaduan menalar secara ilmiah dan etik yang bertolak dari masalah nyata dalam bidang kerjanya.

Lingkungan mempengaruhi pengetahuan seseorang karena segala sesuatu yang ada di sekitar individu, baik lingkungan fisik, biologis, maupun sosial. Lingkungan berpengaruh terhadap proses masuknya pengetahuan ke dalam individu yang berada dalam lingkungan tersebut. $\mathrm{Hal}$ ini terjadi karena adanya interaksi timbal balik 
ataupun tidak yang akan direspon sebagai pengetahuan oleh setiap individu.

Tingkat pendidikan dapat mempengaruhi pengetahuan seseorang. Hal ini terlihat dari seseorang yang berpendidikan rendah akan sulit mencerna istilahistilah yang tidak umum, dibandingkan dengan orang yang berpendidikan tinggi, karena seseorang yang berpendidikan rendah tentu wawasan dan pengetahuannya kurang.

IQ (Intelegency Quation) merupakan salah satu unsur yang mempengaruhi pengetahuan seseorang. semakin tinggi IQ seseorang maka orang tersebut akan semakin cerdas. Dan sini dapat kita ketahui bahwa IQ seseorang itu bisa menentukan besarnya pengetahuan yang diperolehnya, karena orang yang memiliki IQ tinggi kemampuan untuk menyerap ilmu pengetahuannya juga bagus.

Komunikasi mempengaruhi pengetahuan karena seseorang yang memiliki komunikasi yang baik mampu meningkatkan pengetahuan lebih luas. Selain itu melalui komunikasi, seseorang dapat mengembangkan pengetahuan dan meningkatkan kualitas hidup yang dimilikinya sehingga mampu mengikuti kegiatan belajar yang aktif di lingkungan sekolah.
Dalam kegiatan belajar Guru merupakan unsur manusiawi dalam pendidikan, kehadiran guru mutlak diperlukan. Untuk mencapai tujuan pendidikan, guru bertanggung jawab memberikan bimbingan kepada siswanya agar mencapai tingkat pengetahuan yang luas. Guru dan segala keberadaannya merupakan faktor dominan dalam proses pembelajaran di sekolah. Artinya adalah bahwa dalam proses belajar mengajar, guru dituntut sedemikian rupa untuk membangun interaksi dengan siswa guna menyampaikan pesan ajar. Sebab interaksi yang berlangsung antara guru dan siswa merupakan mata rantai yang menghubungkan guru sebagai penyampai pesan ajar dengan siswa sebagai penerima pesan yang berupa pengetahuan. Dalam hal ini, dalam interaksinya dengan siswa dalam pertemuan di kelas, guru harus mampu menciptakan komunikasi yang baik dengan dan antar sesama siswa. Bentuk komunikasi interpersonal yang dimiliki oleh guru pada dasarnya adalah berupa upaya pengiriman pesan atau berita yang berupa materi pelajaran sehingga pesan yang dimaksud dapat dipahami.

Namun saat ini guru kurang memahami kebutuhan belajar siswa. Salah satunya adalah komunikasi 
interpersonal guru terhadap siswa sebagai objek belajar kurang efektif, sehingga siswa merasa tidak tertarik dengan keberadaan guru dan materi yang diembannya. Akibatnya, pengetahuan yang dicapai tidak optimal. Diduga rendahnya pengetahuan siswa juga karena disebabkan oleh komunikasi interpersonal guru yang kurang efektif terhadap siswa, seperti: cara menjelaskan materi dan cara memberikan tugas pelajaran ekonomi kepada siswa, serta kemampuan guru bersosialisasi dengan siswa yang kurang. Akibatnya, siswa merasa tidak terdorong untuk mengikuti sepenuhnya pembejaran ekonomi karena kurangnya ketertarikan dengan keberadaan guru. Maka, sehubungan dengan latar belakang permasalahan $\mathrm{di}$ atas, dapatlah diambil kesimpulan bahwa pelaksanaan komunikasi interpersonal antara guru dan siswa yang baik perlu dan memang sangat penting untuk dilaksanakan oleh guru. Hal itu akan dapat menunjang terlaksana peranannya sebagai guru dengan sebaik-baiknya terutama sebagai komunikator, karena pencapaian pengetahuan siswa tidak akan meningkat apabila komunikasi interpersonal antara guru dan siswanya tidak terjalin dengan baik.
Perumusan Masalah

Berdasarkan latar belakang dan pembatasan masalah di atas, maka dapat dirumuskan sebagai berikut: Apakah terdapat hubungan antara komunikasi interpersonal dengan pengetahuan konsep ekonomi siswa SMU Hutama Pondok Gede?

\section{KAJIAN TEORI}

\section{Pengetahuan tentang Konsep Ekonomi}

Pengetahuan pada hakikatnya merupakan segenap apa yang di ketahui tentang suatu obyek tertentu termasuk di dalamnya ilmu. Pengetahuan diperoleh manusia bersumber dari pengalaman hidupnya dan interaksi sesama manusia serta perubahan-perubahan yang terjadi dengan alam lingkungannya.

Dari berbagai pengalaman manusia akhirnya memperoleh gambaran dalam pikiran yang disebut pengetahuan. Atau dengan kata lain pengetahuan berpangkal pada pikiran atau kemampuan berpikir manusia. Menurut Soekanto pengetahuan adalah "kesan dalam pikiran manusia sebagai hasil penggunaan panca inderanya dan berbeda sekali dengan kepercayaan tahayul dan peneranganpenerangan yang keliru."

Pengetahuan mempunyai ciri khusus yaitu "tentang apa 
(ontology), bagaimana (epistemology) dan untuk apa (aksiology)." Dengan adanya ketiga ciri ini dapat di bedakan berbagai jenis pemikiran manusia yang ada di masyarakat.Pengetahuan merupakan salah satu sumber penting bagi pembentukan perilaku melalui proses belajar. Belajar itu sendiri adalah suatu proses dari seseorang yang berusaha untuk memperoleh bentuk perubahan perilaku yang relative menetap. Belajar memiliki ranah-ranah yang disebut dengan ranah belajar (learning domain). Menurut Bloom bahwa ranah belajar adalah hasil klasifikasi sutu taksonomi tujuan pendidikan yang terdiri atas: "(1) ranah belajar kognitif, (2)

ranah belajar afektif, dan (3) ranah belajar psikomotor." Ranah belajar kognitif adalah ranah yang menaruh perhatian pada pengembangan kapabilitas dan keterampilan intelektual. Ranah belajar afektif yaitu ranah yang berkaitan dengan pengembangan perasaan, sikap, nilai dan emosi. Dan ranah belajar psikomotor yaitu ranah yang berkaitan dengan kegiatankegiatan manipulatif atau keterampilan motorik.

Pada dasarnya pengetahuan merupakan segenap apa yang diketahui tentang suatu objek tertentu. Oleh sebab itu pengetahuan merupakan sumber jawaban bagi berbagai masalah yang muncul dalam kehidupan. Pengetahuan dapat diperoleh melalui belajar. Kegiatan belajar memungkinkan orang memperoleh berbagai kognisi atau Pengertian, kecakapan, keterampilan serta sikap dan perilaku. Pengetahuan dan budaya diwariskan kepada generasi berikutnya melalui proses pendidikan. Dengan demikian apa yang dilihat, didengar oleh setiap anggota masyarakat tidak lepas dari pengaruh kebudayaannya dan berpengaruh pada sikap dan perilakunya.

Manusia mencari pengetahuan dengan harapan bahwa pengetahuan tersebut dapat berguna bagi dirinya untuk membantu memecahkan masalah yang dihadapinya.

Menurut Pollock seperti dikutip oleh Sjamuri membagi wilayah pengetahuan yaitu: (1) pengetahuan persepsi (a posteriori) merupakan pengetahuan yang diperoleh manusi dengan cara mengadakan kontak langsung dengan alam melalui alat-alat indranya; (2) pengetahuan a priori merupakan pengetahuan yang diperoleh manusia tanpa mengadakan kontak langsung dengan alam atau pengetahuan tanpa dasar pengalaman tetapi didasarkan pada penalaran manusia semata-mata; (3) pengetahuan moral merupakan pengetahuan yang 
didasarkan atas ketentuan-ketentuan moral; (4) pengetahuan ingatan merupakan suatu bagian yang amat penting dalam proses penalaran; (5) pengetahuan induksi merupakan pengetahuan yang diperoleh dengan cara melakukan pengamatan. Hasil pengamatan tersebut dengan bantuan statistik dapat disimpulkan sehingga bahan yang terpencar dapat dipahami dalam satu pengertian yang utuh. Sehubungan dengan pendapat di atas, Suriasumantri mengemukakan bahwa "pengetahuan sangat penting dalam kehidupan manusia karena pengetahuan pada hakikatnya merupakan produk kegiatan berpikir, artinya pengetahuan yang diwujudkan dalam pikiran manusia merupakan hasil kegiatan berpikir tentang informasi yang diterima."

Menurut WS. Winkel seperti dikutip oleh Rochayati, konsep adalah satuan arti yang mewakili sejumlah obyek yang memiliki ciri-ciri yang sama. Jadi konsep adalah suatu pengertian yang disimpulkan dari sekumpulan data yang memiliki ciri-ciri yang sama. Selain itu, konsep juga di artikan sebagai suatu abstraksi mengenai suatu kelompok benda atau stimuli yang mempunyai persamaan karakteristik. Konsep memiliki berbagai tingkatan dan hal yang membedakan tingkatan suatu konsep dengan konsep lainnya adalah derajat abstraksi yang dimiliki konsep tersebut.

Mata pelajaran ekonomi adalah salah satu dari 3 mata pelajaran yang diujikan pada tes standar kelulusan siswa SMA/MA dalam ujian nasional. Menurut Prof. PA. Samuelson penerima nobel dalam bidang ilmu ekonomi tahun

1970, dalam bukunya yang berjudul Economics, ia mengemukakan definisi ilmu ekonomi, yaitu:

"Ilmu ekonomi adalah suatu studi tentang perilaku individu dan masyarakat dalam memilih cara menggunakan sumber daya yang langka dan memiliki beberapa alternatif penggunaan, dalam rangka memproduksi berbagai komoditas untuk kemudian menyalurkannya baik saat ini maupun di masa yang akan datang kepada berbagai invidu dan kelompok yang ada dalam suatu masyarakat."

\section{Komunikasi Interpersonal}

Sebagai makhluk sosial, seorang individu dalam menjalani kehidupannya pasti akan berhubungan dengan individu lain. Sarana terbaik untuk menghubungkan manusia satu dengan manusia yang lain adalah komunikasi. Hal ini karena komunikasi merupakan sarana vital untuk dapat 
mengerti diri sendiri dan mengerti orang lain. Istilah komunikasi berpangkal pada perkataan latin yaitu communis yang artinya membuat kebersamaan antara dua orang atau lebih. Komunikasi juga berasal dari kata communion yang artinya membagi. Jadi apabila dua orang terlibat dalam komunikasi, maka komunikasi akan terjadi atau berlangsung selama ada kesamaan makna mengenai apa yang dibicarakan.

Effendy menyebutkan bahwa "komunikasi pada hakekatnya adalah proses penyampaian pikiran atau perasaan oleh komunikator kepada komunikan."16 Dari definisi ini komunikasi dianggap sebagai proses penyampaian pikiran atau perasaan dari komunikator kepada komunikan. Pikiran bisa berupa gagasan, informasi, opini dan lain-lain yang muncul dibenaknya. Perasaan bisa berupa keyakinan, keraguan dan lain-lain yang timbul dari lubuk hati. Informasi, pesan yang disampaikan tentu harus dapat dimengerti oleh komunikator maupun komunikan sehingga jelas maksud dari pesan yang ingin disampaikan oleh komunikator kepada komunikan dan tentunya pikiran-pikiran dari komunikator dapat dipahami, sehingga komunikan dapat melakukan sesuatu sesuai dengan harapan komunikan.
Seiler dikutip oleh Muhammad mengemukakan bahwa "komunikasi adalah proses dengan dimana simbol verbal dan non verbal dikirim, diterima dan diberi arti."17 Sedangkan Rogers dan Kinckaid dalam buku Cangara menjelaskan bahwa "Komunikasi adalah sutu proses dimana dua orang atau lebih membentuk atau melakukan pertukaran informasi dengan satu sama lainnya, yang pada gilirannya akan tiba pada saling pengertian yang mendalam."

Maka komunikasi dapat dikatakan sebagai suatu proses yang dapat mengubah perilaku seseorang melalui penyampaian pesan, gagasan, perasaan dan lain sebagainya. Selanjutnya Supraktiknya menegaskan bahwa komunikasi yang efektif adalah "apabila penerima menginterpretasikan pesan yang di terimanya sebagaimana yang dimaksudkan oleh pengirim". Jadi jelas bahwa komunikasi dapat diartikan sebagai suatu proses apabila tujuan yang hendak dicapai berhasil mengubah pandangan atau perilaku maka terjadilah komunikasi yang efektif. Komunikasi hanya dapat terjadi jika seseorang yang menyampaikan pesan kepada orang lain dengan tujuan tertentu, artinya proses komunikasi hanya bisa terjadi jika didukung oleh komponen atau elemen komunikasi 
yaitu :

1. Sumber komunikasi

2. Pengkodean

3. Pesan

4. Saluran

5. Pengkodean

6. Penerimaan

7. Umpan balik

Kegiatan komunikasi

yang dilakukan manusia sebagian besar berlangsung pada tingkatan komunikasi interpersonal. Seperti yang dikemukakan Ruesch dan Bateson dalam little John yang dikutip dari Alo Liliweri bahwa "tingkatan yang paling penting dalam komunikasi manusia adalah komunikasi interpersonal."

Selanjutnya

pratikto

mengemukakan bahwa komunikasi interpersonal merupakan "komunikasi antara seseorang dengan orang lain yang memungkinkan adanya hubungan yang bebas antara keduanya dan pada umumnya bersifat akrab terbuka dan dapat memantapkan suatu pengertian tentang suatu hal antara seseorang dengan orang lain."

\section{Hipotesis}

"Terdapat hubungan antara Komunikasi Interpersonal dengan Pengetahuan Konsep Ekonomi", sehingga semakin baik komunikasi interpersonal seorang guru maka akan semakin baik pula pengetahuan konsep ekonomi siswa. Sebaliknya, semakin buruk komunikasi interpersonal seorang guru maka semakin rendah pengetahuan konsep ekonomi siswa.

\section{METODOLOGI PENELITIAN}

Berdasarkan masalah yang telah dirumuskan, maka tujuan penelitian ini adalah untuk mengetahui apakah terdapat hubungan antara komunikasi interpersonal dengan pengetahuan konsep ekonomi siswa SMU Hutama di Pondok Gede.

Penelitian ini dilaksanakan di SMU Hutama yang bertempat di Pondok Gede. Waktu penelitian dilaksanakan selama tiga bulan, terhitung sejak bulan September, Oktober dan November 2011

Metode penelitian yang digunakan dalam melaksanakan penelitian ini adalah metode Survey dengan pendekatan korelasional. Metode ini dipilih karena sesuai dengan tujuan penelitian yang ingin dicapai yaitu untuk mengetahui hubungan antara komunikasi interpersonal siswa sebagai variabel $X$ (mempengaruhi) dengan pengetahuan konsep ekonomi sebagai variabel $Y$ (dipengaruhi).

Dalam penelitian ini yang menjadi populasi adalah seluruh siswa SMA Hutama yang berjumlah 438 siswa. Sehingga peneliti 
membuat populasi terjangkau. Populasi terjangkau adalah populasi yang mengandung empat yakni, isi, kesatuan atau unit, tempat atau ruang dan waktu sehingga jenis, karakteristik, jumlah populasi yang ditetapkan. Sedangkan sampel adalah sebagian dari populasi terjangkau yang memiliki sifat yang sama dengan populasi. Populasi terjangkau pada penelitian ini adalah siswa kelas XI IPS SMA Hutama yang terdiri dari empat kelas yang berjumlah 106 siswa. Sedangkan jumlah sampel merujuk pada table dari Isaac dan Michael yang dikutip oleh sugiyono bahwa populasi pada 106 dengan taraf kesalahan $5 \%$, maka jumlah sampelnya sebanyak 84 siswa.

\section{HASIL PENELITIAN}

\section{Persamaan Regresi}

Persamaan regresi yang
dilakukan adalah regresi linear sederhana. Bersamaan regresi ini bertujuan untuk mengetahui apakah terdapat hubungan antara Komunikasi interpersonal dengan Pengetahuan konsep ekonomi siswa.

Analisis regresi linier sederhana terhadap pasangan data penelitian antara Komunikasi interpersonal dengan Pengetahuan konsep ekonomi menghasilkan koefisien arah regresi sebesar 0,194 dan konstanta sebesar
0,44. Dengan demikian bentuk hubungan antara komunikasi interpersonal (variabel $\mathrm{X}$ ) dan pengetahuan konsep ekonomi (variabel $Y$ ), memiliki persamaan regresi $\hat{Y}=0,44+0,194 \mathrm{X}$. Persamaan regresi tersebut menunjukkan bahwa setiap kenaikan satu skor komunikasi interpersonal akan mengakibatkan pengetahuan konsep ekonomi pada mata pelajaran ekonomi sebesar 0,194 skor pada konstanta 0,44 .

\section{Uji Keberartian Koefisien Regresi}

Pengujian ini dilakukan untuk mengetahui berarti tidaknya variabel $X$ dan $Y$ yang telah dibentuk melalui persamaan regresi linier sederhana. Kriteria pengujian terima $\mathrm{Ho}$ jika $\mathrm{Fh}(\mathrm{h} / \mathrm{a})<\mathrm{Ft}$ dimana regresi tidak berarti, tolak Ho jika $\mathrm{Fh}(\mathrm{h} / \mathrm{a})>\mathrm{Ft}$ dimana Ho adalah model regresi berarti. Berdasarkan hasil perhitungan uji keberartian regresi dengan menggunakan tabel ANAVA diperoleh nilai $F_{h}$ sebesar 37,40 dan $F t$ dengan dk pembilang 1 dan dk penyebut 82 pada taraf signifikan $5 \%$ diperoleh angka 3,96 karena Fhitung > Ftabel, maka $\mathrm{H}_{\mathrm{o}}$.

Dengan demikian disimpulkan bahwa koefisien regresi tersebut berarti atau dengan kata lain hubungan Komunikasi interpersonal dengan 
Pengetahuan konsep ekonomi adalah berarti atau signifikan.

\section{Uji Linearitas Regresi}

Perhitungan uji linearitas regresi digunakan untuk mengetahui apakah koefisien regresi tersebut berbentuk linier atau non linier. Untuk mengetahui linearitas dari sebuah regresi maka perlu dicari nilai $F$, karena untuk menguji liniearitas regresi digunakan kriteria pengujian terima Ho jika Fhitung < Ftabel sehingga koefisien regresi dikatakan linear jika berhasil menerima Ho.

Analisis regresi linier sederhana pasangan data penelitian antara variabel komunikasi interpersonal dengan Pengetahuan konsep ekonomi memiliki persamaan regresi sebagai berikut $\hat{Y}=0,44+0,194 X$. dengan persamaan regresi tersebut diperoleh perhitungan yang disajikan dalam tabel IV.5

Dari hasil perhitungan uji keberartian regresi dengan menggunakan tabel ANAVA diatas diperoleh Fhitung sebesar 37,40 dan Ftabel dengan derajat kebebasan pembilang 1 dan derajat kebebasan penyebut 82 pada taraf signifikansi $5 \%$ adalah 3,96 karena Fhitung > Ftabel, maka Ho diterima. Dengan demikian, dapat disimpulkan bahwa koefisien regresi tersebut signifikan.

Sedangkan hasil perhitungan uji linearitas dengan menggunakan tabel ANAVA diatas diperoleh Fhitung sebesar 1,38 dan Ftabel dengan derajat kebebasan pembilang

35 dan derajat kebebasan penyebut (n-k) 47 pada taraf signifikansi $5 \%$ adalah 1,71 karena Fhitung < Ftabel, maka Ho diterima. Dengan demikian, dapat disimpulkan bahwa koefisien regresi tersebut linier.

\section{Perhitungan Koefisien Korelasi}

Penentuan koefisien korelasi bertujuan untuk mengetahui kuat atau tidaknya hubungan antar variabel $X$ dan Y. Perhitungan koefisien korelasi menggunakan rumus koefisien korelasi product moment dari pearson. Dari hasil perhitungan diperoleh $r x y=0,560>$ dari 0 maka dapat disimpulkan bahwa hubungan antara variabel $X$ dan $Y$ hal ini positif.

\section{Uji Keberartian Koefisien Korelasi (dengan Uji-t)}

Untuk mengetahui keberartian antara variabel $X$ dengan $Y$ yaitu dengan menggunakan uji-t pada taraf signifikan $\alpha=0,05$ dengan $d k=n-$ 2. Kriteria pengujiannya adalah terima Ho jika thitung < tabel maka koefisien korelasi yang terjadi berarti. Hasil perhitungan menunjukkan thitung 
sebesar 6,12 dan ttabel sebesar 1,67. Karena thitung $>$ tabel maka Ho ditolak sehingga dapat disimpulkan bahwa terdapat hubungan yang signifikan antara variabel $X$ dengan variabel $Y$ dan berarti.

Hipotesis

objektif

menyatakan bahwa tidak terdapat hubungan yang berarti antara komunikasi interpersonal (X) dengan pengetahuan konsep ekonomi $(\mathrm{Y})$, dan Hipotesis alternatif $\left(\mathrm{H}_{\mathrm{i}}\right)$ menyatakan terdapat hubungan yang berarti antara komunikasi interpersonal $(X)$ dengan pengetahuan konsep ekonomi $(Y)$. Kriteria pengujiannya adalah terima $\mathrm{H}_{\mathrm{O}}$ jika thitung < tabel dan tolak $\mathrm{H}_{\mathrm{O}}$ jika thitung $>$ ttabel. Berdasarkan pengujian keberartian koefisien korelasi antara Komunikasi interpersonal $(X)$ dengan pengetahuan konsep ekonomi $(Y)$, didapat thitung sebesar 6,12 dan ttabel pada taraf signifikansi $5 \%$ dengan $\mathrm{dk}(\mathrm{n}-2)=84-2$ = 82 sebesar 1,67 hal ini menunjukkan bahwa thitung > ttabel yang artinya terdapat hubungan yang berarti antara Komunikasi interpersonal (X) dengan Pengetahuan konsep ekonomi $(Y)$.

Berdasarkan pengujian signifikansi koefisien korelasi antara pasangan skor antara komunikasi interpersonal dengan pengetahuan konsep ekonomi sebagaimana terlihat pada tabel IV.6, diperoleh thitung $=$ $6,12,>$ tabel $=1,67$, Jadi dapat disimpulkan bahwa koefisien korelasi $r_{x y}=0,560$ dinyatakan signifikan berdasarkan pengujian rhitung $($ rxy $)>0$ atau $\rho>0$, artinya dapat diketahui bahwa terdapat hubungan positif antara Komunikasi interpersonal dengan Pengetahuan konsep ekonomi pada SMA Hutama di Pondok Gede.

\section{Koefisien Determinasi}

Koefisien determinasi dilakukan untuk mengetahui besarnya variasi kontribusi variabel bebas (komunikasi interpersonal) terhadap variabel terikat (pengetahuan konsep ekonomi). Mencari koefisien determinasi adalah $K D=\operatorname{rxy}^{2}$ yaitu $K D=0,560^{2}$, berdasarkan hasil perhitungan diperoleh nilai koefisien determinasi (KD) sebesar 0,3132. Hal ini berarti bahwa 31,32\% pengetahuan konsep ekonomi ditentukan oleh komunikasi interpersonal, sedangkan sisanya $68,68 \%$ dipengaruhi oleh faktor lain.

\section{Pembahasan}

Berdasarkan hasil perhitungan statistik yang telah dilakukan maka dapat terlihat adanya hubungan yang positif antara komunikasi interpersonal terhadap pengetahuan konsep ekonomi pada SMA Hutama di 
Pondok Gede. Berdasarkan hasil perhitungan yang telah dikemukakan uji keberartian regresi diperoleh Fhitung $=37,40$ dan Ftabel $=3,96$ maka Fhitung $>$ Ftabel ini menunjukkan bahwa hubungan komunikasi interpersonal dengan pengetahuan konsep ekonomi adalah berarti atau signifikan dan uji linearitas diperoleh Fhitung $=1,38$ dan Ftabel $=$ 1,71 maka Fhitung < Ftabel ini berarti bahwa keofisien regresi tersebut liniear.

Pola hubungan antara kedua variabel ini dinyatakan oleh persamaan regresi $\hat{Y}=0,44+0,194 X$, persamaan ini memberikan informasi bahwa perubahan 1 tingkat komunikasi interpersonal dapat mengakibatkan terjadinya perubahan pada pengetahuan konsep ekonomi pada mata pelajaran ekonomi sebesar 0,194 pada konstanta 0,44 .

Hasil analisis korelasi sederhana antara komunikasi interpersonal dengan pengetahuan konsep ekonomi diperoleh nilai keofisien korelasi rxy sebesar 0,560. Nilai ini menunjukkan adanya hubungan positif antara komunikasi interpersonal dengan pengetahuan konsep ekonomi. Karena nilai $r$ sebesar 0,560 artinya semakin baik komunikasi interpersonal maka akan semakin tinggi pula pengetahuan konsep ekonomi. Sebaliknya, semakin buruk komunikasi interpersonal akan semakin rendah pengetahuan konsep ekonomi. Menurut Sugiyono, pedoman untuk interpretasi koefisien korelasi adalah sebagai berikut : 57

0,00-0,1999 = Sangat Rendah

$0,20-0,3999=$ Rendah

$0,40-0,5999=$ Sedang

$0,60-0,7999=$ Kuat

$0,80-1,00=$ Sangat Kuat

Oleh karena itu, nilai koefisien korelasi sebesar 0,560 termasuk kedalam interpretasi koefisien korelasi kategori sedang karena nilai tersebut ada pada kelompok 0,40 - 0,5999. Perhitungan koefisien determinasi (KD) diperoleh hasil 0,3132 secara statistik nilai ini memberikan pengertian bahwa kurang lebih 0,3132 variasi data pengetahuan konsep ekonomi SMA Hutama dipengaruhi oleh komunikasi interpersonal. Hasil koefisien determinasi diatas menunjukkan bahwa komunikasi interpersonal adalah salah satu faktor yang mempengaruhi pengetahuan konsep ekonomi.

Oleh karena itu, pengetahuan konsep ekonomi tidak hanya tumbuh dan berkembang dari dalam diri tetapi pengetahuan konsep ekonomi dipengaruhi oleh beberapa faktor yang timbul dari luar diri. Salah satu faktor 
yang mempengaruhi pengetahuan konsep ekonomi adalah komunikasi interpersonal. Dalam hal ini, komunikasi interpersonal juga berperan aktif dalam menumbuhkan dan mengembangkan pengetahuan konsep ekonomi, karena dengan diterapkannya komunikasi interpersonal yang baik, siswa merasa nyaman dan tertarik untuk disiplin sehingga tujuan pengajaran pun tercapai. Maka dari itu, hasil perhitungan koefisien determinasi (KD) diperoleh sebesar dari pengaruh komunikasi interpersonal dalam KBM terhadap pengetahuan konsep ekonomi sebesar 0,3132. Sedangkan sisanya ditentukan oleh faktor-faktor lain seperti pengalaman, lingkungan, tingkat pendidikan, IQ.

Berdasarkan perhitungan skor rata-rata sub indikator komunikasi interpersonal pada tabel VI.4 maka hasil penelitian diinterpretasikan bahwa sub indikator yang paling berpengaruh adalah kemampuan untuk menjalin komunikasi dalam KBM dengan persentase sebesar 16,76\% karena dengan adanya kemampuan untuk menjalin komunikasi dalam KBM siswa semakin mengerti dan memahami pengetahuan konsep ekonomi. Sedangkan pada tabel VI.2 hasil penelitian diinterpretasikan bahwa pengetahuan konsep ekonomi adalah pada sub indikator mengklasifikasi ketenagakerjaan dengan persentase sebesar 12,60\%. $\mathrm{Hal}$ ini menunjukkan dengan komunikasi interpersonal dalam KBM yang semakin baik akan meningkatkan pengetahuan konsep ekonomi. Sebaliknya semakin buruk komunikasi interpersonal dalam KBM maka rendahnya pengetahuan konsep ekonomi pada SMA Hutama di Pondok Gede.

\section{KESIMPULAN DAN SARAN \\ Kesimpulan}

Hasil penelitian menunjukkan bahwa terdapat hubungan yang positif antara komunikasi interpersonal dengan pengetahuan konsep ekonomi di SMA Hutama. Hal ini berdasarkan hasil perhitungan koefisien korelasi sebesar 0,560. Maka dapat disimpulkan bahwa semakin baik komunikasi interpersonal dalam KBM maka akan semakin tinggi pula pengetahuan konsep ekonomi siswa.

Berdasarkan
koefisien determinasi $(\mathrm{KD})$ maka
didapat 0,3132 artinya pengetahuan
konsep ekonomi di SMA Hutama
ditentukan oleh komunikasi
interpersonal dalam KBM. Hal ini
menunjukkkan bahwa pengetahuan
konsep ekonomi akan meningkat jika
komunikasi interpersonal dalam KBM
baik sehingga pengetahuan konsep


ekonomi dapat dipertahankan dan sisanya sebesar 0,6868 ditentukan oleh faktor-faktor lain.

\section{Saran}

Berdasarkan kesimpulan dan
implikasi diatas, saran-saran yang
kiranya dapat diberikan oleh peneliti
adalah :

1. Guru

berperan

dalam

meningkatkan pengetahuan konsep ekonomi karena Mata pelajaran ekonomi adalah salah satu dari 3 mata pelajaran yang diujikan pada tes standar kelulusan siswa SMA/MA dalam ujian nasional. Melalui upaya yaitu melibatkan siswa secara optimal dalam pembelajaran ekonomi.

2. Guru bekerja sama dengan siswa dalam kegiatan belajar mengajar untuk meningkatkan pengetahuan siswa melalui upaya menjalin komunikasi dengan semua siswa dengan melakukan pendekatanpendekatan ke siswa, memahami latar belakang siswa dan memberi pembinaan khusus bagi siswa yang bermasalah dalam nilai pengetahuan ekonominya.

\section{DAFTAR PUSTAKA}

A, Sjamsuri S. Pengantar Teori Pengetahuan. Jakarta: P2LPTK Depdikbud, 1989. Arikunto,
Suharsimi. Dasar-dasar Evaluasi Pendidikan. Jakarta: Bumi Aksara,2009. Arikunto, Suharsimi. Prosedur Penelitian Suatu Pendekatan Praktek. Jakarta: PT Rineka Cipta, 1996.

Bloom, B.S. Taxonomy of Educational Objektives: The Classification of Educational Goals, Handbook 1, Cognitive domain. New York: David Mekay Company Inc, 1966. Boediono dan Wayan Koster, Teori dam Implikasi Statitiska dan Probablitas. Bandung: PT. Remaja Rosdakarya, 2001.

Cahyana, Yan-Yan dan Bagong Suyanto. Kajian Komunikasi dan seluk Beluknya. Surabaya: Airlangga Univ.Press.

Cangara, Hafied. Pengantar IImu Komunikasi. Jakarta: PT. Raja Grafindo Persada, 2006.

Depdiknas, Tim Litbang. Panduan Materi Ujian Nasional SMA. Jakarta: Departemen Pendidikan Nasional, 2005.

Djaali, et.al. Pengukuran Bidang Pendidikan. Jakarta, PPS UNJ, 2000.

Djuarsa, Sasa. Pengantar Komunikasi, Modul Universitas Terbuka. Jakarta: Universitas Terbuka, 1993.

Easterby-Smith, et. al. Organizational learning: Debates past, present 
and future. Journal of Management Studies , 37(6), 2000.

Effendy, Onong Uchajana. IImu Komunikasi, teori dan praktek. Bandung: Remaja Rosdakarya, 2006.

Gredler, Bell. Belajar dan membelajarkan, Terjemahan Munandir. Jakarta: Rajawali, 1991.

Habibi, Maksum. Ekonomi untuk SMU kelas I. Jakarta: PT. Piranti Darma Kalotama, 2002.

Hasan, Hamid. Arti Konsep Dasar dan IImu Sosial. Jakarta: Karunika, 1986. Jalaludin, Rahmat. Psikologi Komunikasi. Bandung: Remaja Rosdakarya, 1992.

Liliweri, Alo. Persepektif Teoritis Komunikasi Antarpribadi. Bandung: Cinta Aditya Bhakti, 1994.

Manulang, M.. Pengantar Ekonomi Perusahaan. Jakarta: Ghalia Indonesia, 1996. Muhammad, Arni. Komunikasi Organisasi. Jakarta: Bumi Aksara, 2002.

PR, Carlie. Transferring, translating and transforming: An intergratif framework for managing knowledge across boundaries. Organization Science , 15(5), 2004.

Pratikto, Riyono. Komunikasi Sosial.
Bandung: Remaja Karya, 1990.

Robbins, Stephen P. Perilaku Organisasi, Konsep, Kontroversi dan Aplikasi. Jakarta: PT. Prenhallindo, 2003.

Rochayati, Umi Nur. "Pemahaman Konsep Dasar IImu Ekonomi untuk Tujuan Pendidikan Ekonomi" Hasil Penelitian. Jakarta: Lembaga Penelitian IKIP Jakarta, Juli 1991.

Rochayati, Umi Nur. Pengantar Ekonomi. Jakarta: FPIPS IKIP Jakarta, 1984.

S, Azwar. Sikap Manusia, Teori dan Pengukurannya, Cetakan VII. Yogyakarta: Pustaka Pelajar Offset, 2003.

Sendjaja,Sasa Djuarsa. Pengantar Komunikasi, Jakarta: UT, 1993. Soekanto, Soerjono. Sosiologi: Suatu Pengantar. Jakarta: Rajawali, 1988.

Stanton, W.J, and Richard H. Buskrik. Teknik dan Strategi Pemasaran Alih Bahasa D.H. Gulo, Jakarta: Arikha Media Cipta, 1996.

Sudjana, Nana. Penelitian dan Penilaian Pendidikan, Bandung: Sinar Baru, 1989. Sudjana. Metode Statistika .Bandung: Tarsito, 2005.

Sugiyono, Metode Penelitian

Administrasi, Bandung: Alfabeta, 2009.

Sukirno, Sadono. Pengantar Teori 
Ekonomi Mikro. Jakarta: PT. Raja Grafindo Persada, 1995.

Supraktiknya, A. Komunikasi Antar Pribadi, Tinjauan Psikologis, Jakarta: Kanisius, 1995.

Suriasumantri, Jujun S. Filsafat IImu:

Sebuah pengantar popular. Jakarta: Sinar Harapan, 1985.

Suriasumantri, Jujun S. Tentang hakikat IImu: Sebuah Pengantar redaksi IImu dan Perspektif. Jakarta: Gramedia

Y, Rusyiati. Pengaruh Komunikasi terhadap perilaku kepala keluarga dalam pencegahan malaria. Jurnal Epidemiology Nasional, Vol. 3. 